\title{
Sample Preparation for Microstructural Characterization of Ni-Yttria-Stabilized Zirconia Anodes
}

\author{
Soo-Man Sim ${ }^{\dagger}$ \\ Department of Materials Engineering, Hongik University, Sejong 30016, Korea \\ (Received April 30, 2018; Revised June 4, June 24, 2018; Accepted June 25, 2018)
}

\begin{abstract}
Microstructural characterization of Ni-yttria-stabilized zirconia (YSZ) anodes using secondary electron images has been limited by a lack of contrast between Ni and YSZ phases. This paper reports a sample preparation method for obtaining secondary electron images that allow the detection of $\mathrm{Ni}$, YSZ, and pore phases together. Ni-YSZ anode samples were obtained by reducing NiO-YSZ samples prepared by using the mixed oxide method. Colloidal silica polishing and electrolytic etching were performed on the Ni-YSZ samples. The morphological change of the sample surface after each polishing process is examined.
\end{abstract}

Key words : NiO-YSZ, Ni-YSZ, Microstructure, Polishing, Electrolytic Etching

\section{Introduction}

$M^{2}$ any researchers have been trying to understand the correlation between the properties and the microstructure of Ni-yttria-stabilized zirconia (YSZ) anodes for improving the performance of solid oxide fuel cells. ${ }^{1-7)}$ Quantitative image analysis is used to investigate the correlation, but microstructural parameters such as sizes and distributions, volume fractions, continuities, and interfacial areas of the constituent phases need to be investigated. However, much time and extensive efforts are required to determine microstructural parameters because it is not easy to discern the constituent phases from microscopic images.

Optical microscopes have been widely used in metallography, but the low magnification and resolution limit the quantitative image analysis of $\mathrm{Ni}-\mathrm{YSZ}$ anodes. The $\mathrm{Ni}$ phase is easily identified because it yields a much brighter image than the other phases; however, the YSZ and pore phases yield dark gray images and are not readily distinguishable. It was reported that YSZ and pore phases could be separated by carefully adjusting the brightness and contrast of the images. ${ }^{2,8)}$ A scanning electron microscope (SEM) provides images of high magnification and good resolution. However, it is difficult to identify $\mathrm{Ni}$ and YSZ phases in secondary electron (SE) images because Ni and YSZ phases have very similar backscatter coefficients, which result in a lack of contrast between the two phases. ${ }^{2,8)}$ YSZ and pore images have been extracted after removal of $\mathrm{Ni}$ by acid etching. ${ }^{3)}$ It was claimed that the contrast between $\mathrm{Ni}$ and YSZ could be attained with an SEM at a low acceleration voltage $(\leq 1 \mathrm{kV})$ and a slow scan rate. ${ }^{9)}$ However, nei-

\footnotetext{
Corresponding author: Soo-Man Sim

E-mail : smsim@hongik.ac.kr

Tel : +82-44-860-2518 Fax : +82-44-862-2774
}

ther method is straightforward because the analysis needs careful microscope manipulation and many image-processing steps. Therefore, it will be beneficial in the quantitative image analysis of Ni-YSZ anodes for the microstructural parameters to be determined directly from the SE images.

In this paper, a sample preparation method for microstructural characterization of Ni-YSZ anodes is described. Colloidal silica polishing and electrolytic etching were attempted to obtain SE images, allowing the detection of $\mathrm{Ni}$, YSZ, and pore phases simultaneously. The morphological change of the sample surfaces after each polishing process was monitored.

\section{Experimental Procedure}

NiO-YSZ samples were prepared using NiO (Sumitomo) and YSZ (Tosoh, TZ-8Y) powders. The powders were mixed and milled in an attrition jar. The powder mixture was mixed with a binder (polyvinylpyrrolidone (PVP), SigmaAldrich) and pressed into pellets of $15 \mathrm{~mm}$ in diameter at 50 $\mathrm{MPa}$. The pellets were heated at $600^{\circ} \mathrm{C}$ to remove the binder and subsequently sintered at $1350^{\circ} \mathrm{C}$ for $4 \mathrm{~h}$ in air. The sintered NiO-YSZ samples were reduced at $900^{\circ} \mathrm{C}$ for $3 \mathrm{~h}$ in a reducing atmosphere $\left(96 \% \mathrm{Ar}\right.$ and $\left.4 \% \mathrm{H}_{2}\right)$. The amount of $\mathrm{Ni}$ was $40 \mathrm{vol} \%$ (50 wt\%), which corresponded to $52.4 \mathrm{vol} \%$ (56 wt\%) of $\mathrm{NiO}$.

$\mathrm{NiO}-\mathrm{YSZ}$ and Ni-YSZ samples were polished with 3- and $1-\mu \mathrm{m}$ diamond pastes for $48 \mathrm{~h}$, respectively, in a vibratory polisher (VibroMet 2, Buehler). The polishing was continued with $0.25-\mu \mathrm{m}$ diamond paste for up to $96 \mathrm{~h}$ until no scratches were found. Additional polishing was performed with a colloidal silica suspension $(0.04 \mu \mathrm{m}$, Struers $)$ for up to $144 \mathrm{~h}$. Electrolytic etching of Ni-YSZ samples was performed in an electropolisher (ElectroMet 4 equipped with a stainless-steel cathode, Buehler). The applied voltage was 6 

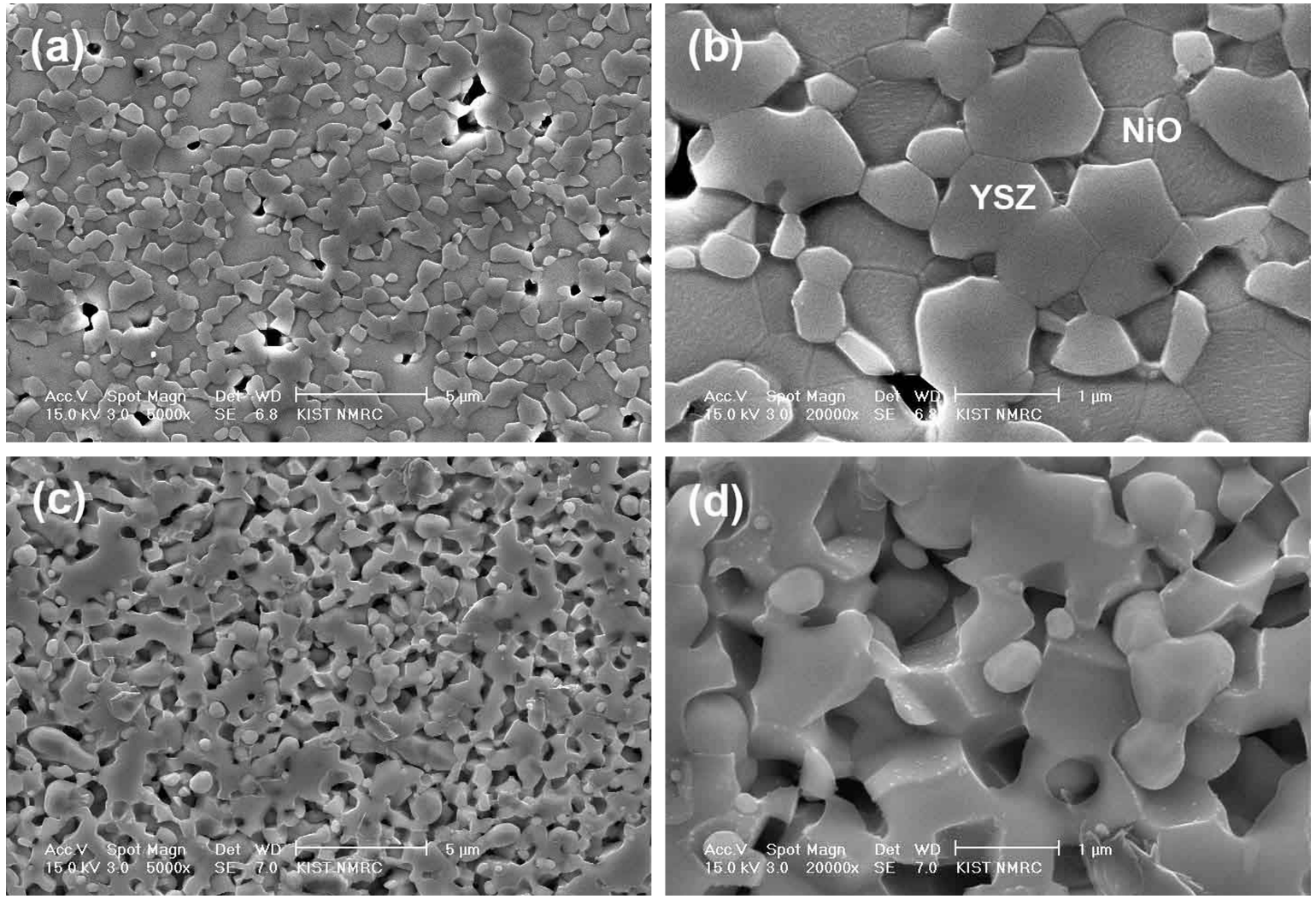

Fig. 1. SEM micrographs of $(a, b)$ NiO-YSZ sample polished with silica and $(c, d)$ reduced Ni-YSZ.
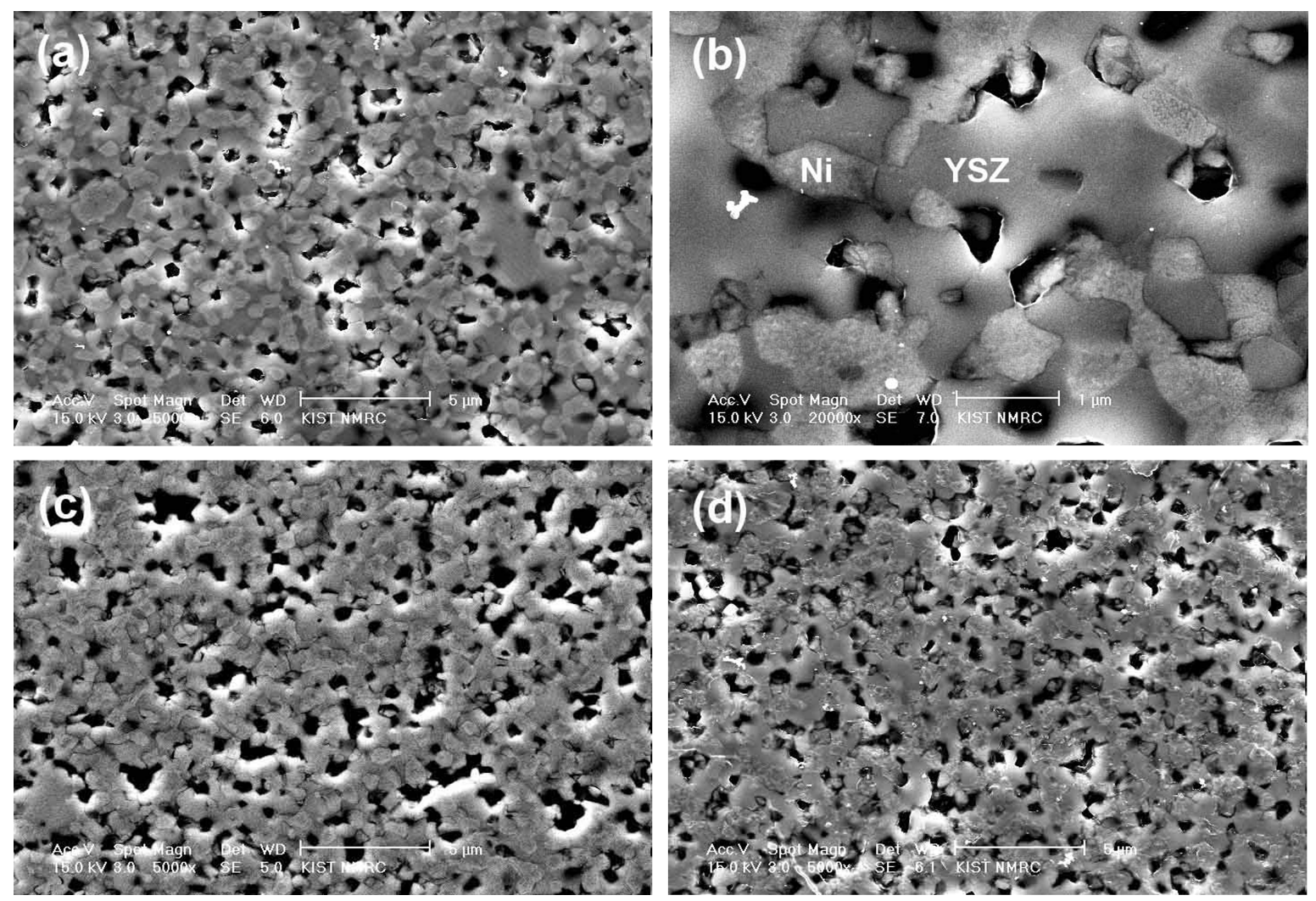

Fig. 2. SEM micrographs of Ni-YSZ samples electrolytically etched at $6 \mathrm{~V}$ for (a, b) $3 \mathrm{~s}$, (c) $6 \mathrm{~s}$, and (d) $9 \mathrm{~s}$. 
$\mathrm{V}$, and an oxalic acid solution (10 wt\%) was used as an etchant. $^{10)}$

SE images of the polished and etched samples were obtained at an acceleration voltage of $15 \mathrm{~V}$ with an SEM (FEI XL-30 FEG, FEI). NiO, Ni, and YSZ phases were identified with energy-dispersive X-ray spectroscopy (EDX). Before the SEM observation, NiO-YSZ samples were ther-
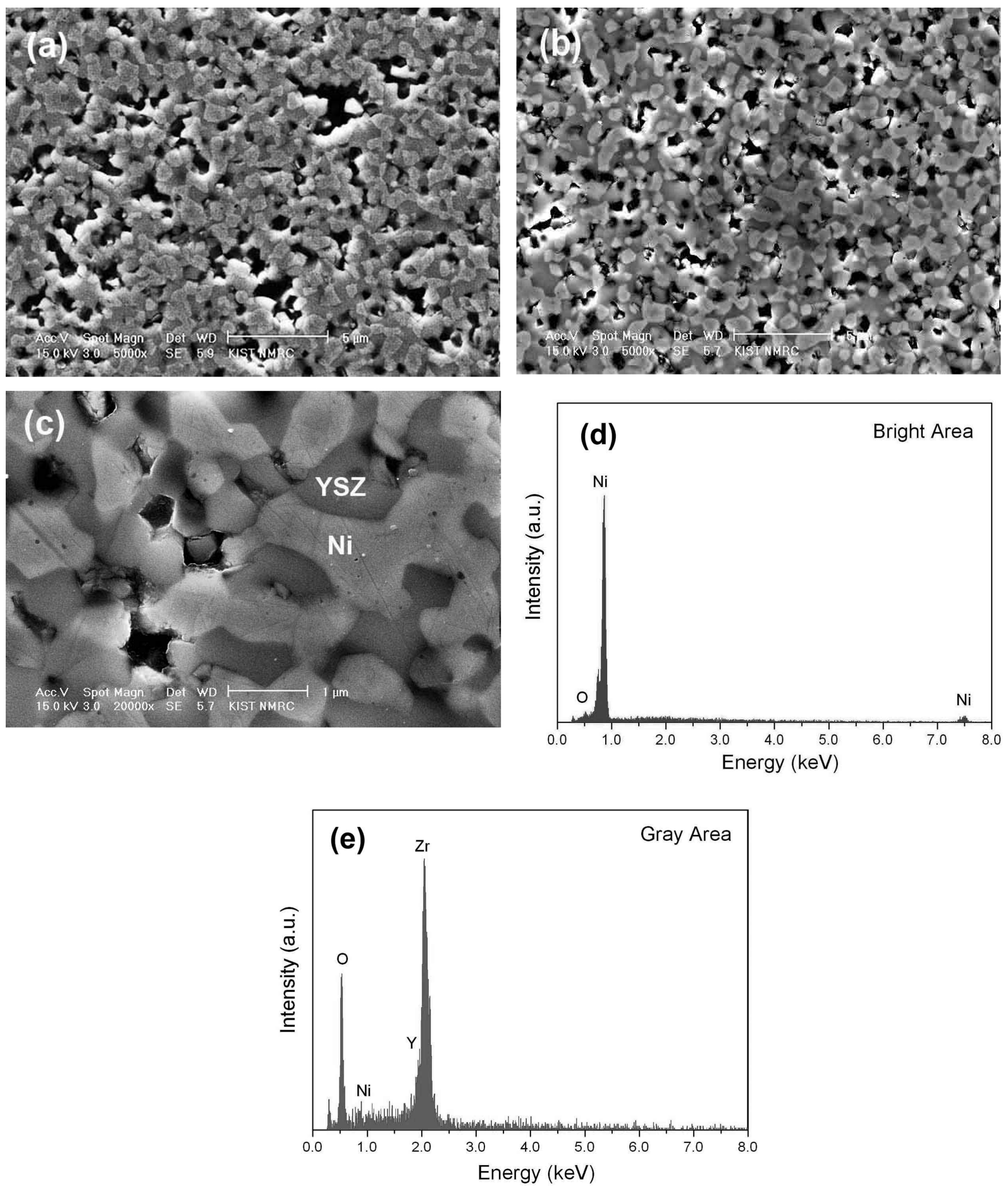

Fig. 3. SEM micrographs of Ni-YSZ samples polished (a) with diamond paste for $96 \mathrm{~h}$ and (b-c) silica for $144 \mathrm{~h}$. EDX spectra of (d) bright and (e) dark grains in (c). mally etched at temperature $150^{\circ} \mathrm{C}$ below the sintering temperature for $30 \mathrm{~min}$.

\section{Results and Discussion}

Polishing of NiO-YSZ samples with a silica suspension resulted in SEM images showing distinctive features of $\mathrm{NiO}$ 
and YSZ phases. Figs. 1(a) and (b) show SEM images of $\mathrm{NiO}-\mathrm{YSZ}$ samples sintered at $1350^{\circ} \mathrm{C}$ and polished with diamond paste for $72 \mathrm{~h}$ and then silica for $144 \mathrm{~h}$. NiO and YSZ grains in the size range of $\sim 1-2 \mu \mathrm{m}$ are visible (Fig. 1(a)), and their grain boundaries are seen in the higher magnification image (Fig. 1(b)). Such morphology is attributed to a selective abrasion of $\mathrm{NiO}$. Because silica is harder $\left(\mathrm{H}_{\mathrm{v}} \sim 7\right.$ $\mathrm{GPa})$ than $\mathrm{NiO}\left(\mathrm{H}_{\mathrm{v}} \sim 5.7 \mathrm{GPa}\right)$ but softer than $\mathrm{YSZ}\left(\mathrm{H}_{\mathrm{v}} \sim 12\right.$ $\mathrm{GPa}), \mathrm{NiO}$ is more abraded than YSZ in the lengthy polishing process. ${ }^{11)}$ After reducing the polished NiO-YSZ sample, the Ni-YSZ sample was expected to exhibit similar morphology to that of the NiO-YSZ sample, because only $\mathrm{NiO}$ was reduced to $\mathrm{Ni}$ and YSZ remained intact. However, the outlines of $\mathrm{Ni}$ and YSZ phases were lost entirely, and a rough surface with protruded $\mathrm{Ni}$ particles was observed (Figs. 1(c) and (d)).

For a better detection of the Ni phase, electrolytic etching was performed on the Ni-YSZ samples polished with diamond paste. Figs. 2(a) and (b), (c), and (d) show SEM images of the Ni-YSZ samples etched at $6 \mathrm{~V}$ for 3,6 , and $9 \mathrm{~s}$, respectively. Etching for $3 \mathrm{~s}$ produced the best image: all the $\mathrm{Ni}$ grains were etched throughout the sample (Fig. 2(a)). The etched $\mathrm{Ni}$ phase appears as light gray particles and the unetched YSZ phase appears as a gray area. However, some areas with an unevenly outlined Ni phase were observed in the high magnification image (Fig. 2(b)). Etching for 6 and 9 s yielded images in which it was difficult to distinguish between the Ni and YSZ phases. The image obtained after etching for $6 \mathrm{~s}$ showed some $\mathrm{Ni}$ grain boundaries that were sharply but unevenly etched (Fig. 2(c)). After etching for $9 \mathrm{~s}$, the surfaces of the $\mathrm{Ni}$ phase were covered with the precipitates (Figs. 2(d)) as a result of the excessive etching. The precipitates were made of $\mathrm{Ni}$ oxalate dihydrate $\left(\mathrm{Ni}\left(\mathrm{C}_{2} \mathrm{O}_{4}\right) \cdot 2 \mathrm{H}_{2} \mathrm{O}\right)$, which was formed by the reaction between the $\mathrm{Ni}^{2+}$ ions dissolved from $\mathrm{Ni}$ and the oxalate ions $\left(\mathrm{HC}_{2} \mathrm{O}_{4}^{-}\right)$ existing in the etching solution at $1 \leq \mathrm{pH} \leq 5 .{ }^{12)}$ The results of the electrolytic etching seem to be unsatisfactory for image analysis.

The Ni-YSZ samples were polished using the same process as for NiO-YSZ samples to obtain images of the better contrast between Ni and YSZ. Figs. 3(a) and (b) show SEM images of Ni-YSZ samples polished with only diamond paste and with diamond paste and silica, respectively. Polishing with diamond paste gave an image in which $\mathrm{Ni}$ and YSZ phases were barely visible (Fig. 3(a)). The contrast between $\mathrm{Ni}$ and YSZ was not sufficient for image analysis. As shown in Fig. 3(b), polishing with silica resulted in images with better contrast between $\mathrm{Ni}$ and YSZ compared to Fig. 3(a). Figs. 3(d) and (e) show EDX spectra of the image in (c). The bright area corresponds to the Ni phase and the gray area to the YSZ phase. It should be mentioned that the effect of silica polishing could be observed only in
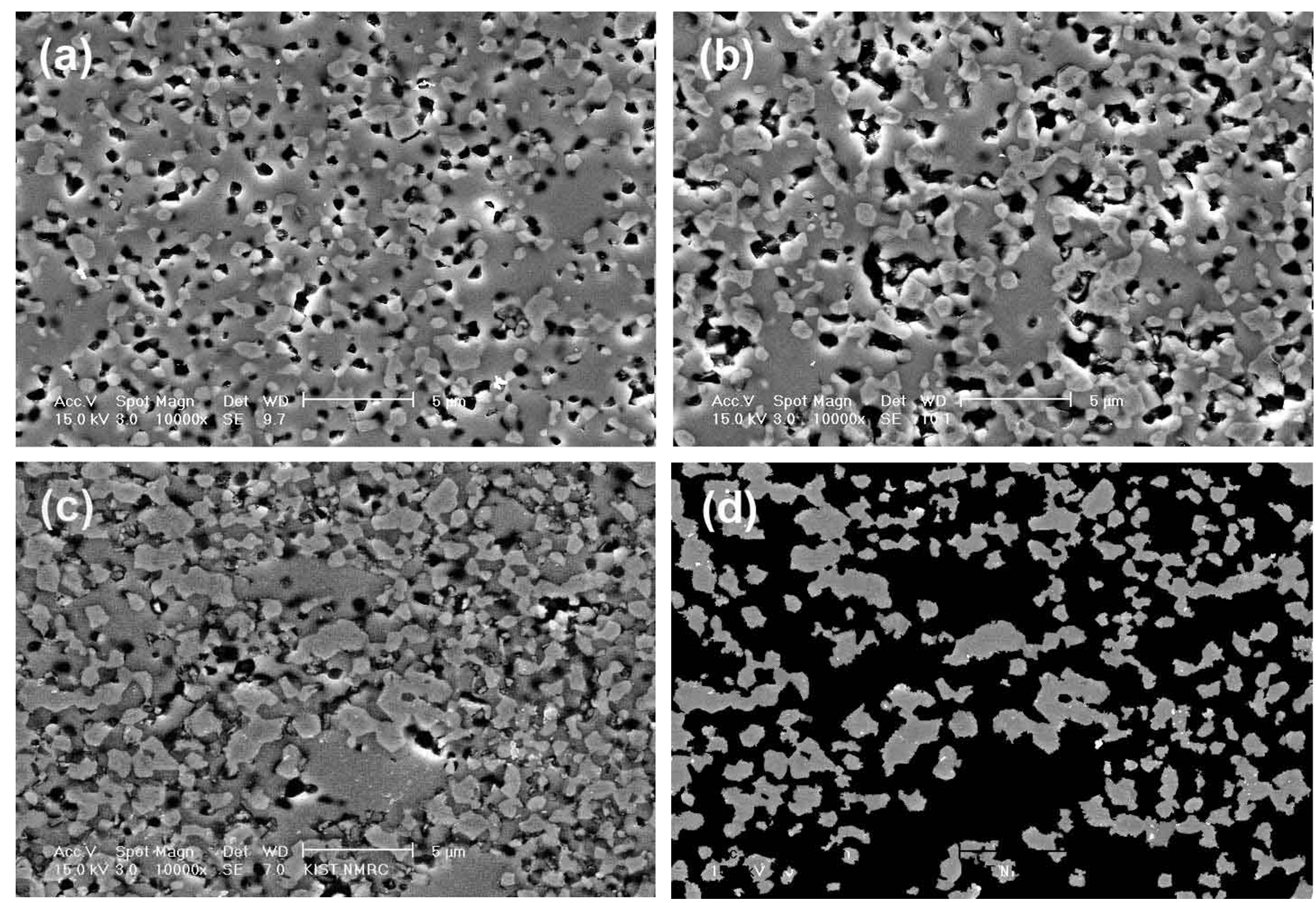

Fig. 4. SEM micrographs of Ni-YSZ samples polished with silica: (a) 20 vol\% Ni, (b) 30 vol\% Ni, and (c) 40 vol\% Ni. (d) presents Ni-phase distribution extracted from the image of (c). 
the samples that had been carefully polished with diamond paste because surface abrasion by colloidal silica occurred very slowly.

Figures 4(a), (b), and (c) show SEM images of Ni-YSZ containing 20,30, and $40 \mathrm{vol} \% \mathrm{Ni}$, respectively. After a minor adjustment of the brightness and contrast of the image with an image-processing program (Photoshop, Adobe), Ni, YSZ, and pore phases became more visible. Gray particles are the Ni phase and dark areas are the YSZ and pore phases. The $\mathrm{Ni}$ phase can be seen more with increasing Ni vol\%. Fig. 4(d) shows the Ni image that was extracted from the image using image processing and successfully used in determining the volume fraction of the Ni phase. The volume fraction of the Ni phase measured from SEM images of the Ni-YSZ sample containing $40 \mathrm{vol} \% \mathrm{Ni}$ was found to be 0.342 , which was close to the real value of 0.336 .

\section{Conclusions}

Colloidal silica polishing and electrolytic etching were performed on Ni-YSZ samples to obtain an SE image, allowing the detection of $\mathrm{Ni}$, YSZ, and pore phases together. Polishing of an NiO-YSZ sample with a colloidal silica suspension provides a distinctive SE image of $\mathrm{NiO}$ and YSZ phases owing to the difference in the hardness between silica and the constituent phases. Electrolytic etching of an Ni-YSZ sample at $6 \mathrm{~V}$ for $3 \mathrm{~s}$ yielded the best image of the Ni phase. However, the image was unsuitable for image analysis because some areas with an unevenly outlined the Ni phase were observed. Polishing of Ni-YSZ samples with silica provided images with sufficient contrast between the $\mathrm{Ni}$ and YSZ phases. The SE images obtained at an acceleration voltage of $15 \mathrm{~V}$ and by adjusting the brightness and contrast were found to be suitable for quantitative image analysis.

\section{REFERENCES}

1. T. Iwata, "Characterization of Ni-YSZ Anode Degradation for Substrate-Type Solid State Fuel Cells," J. Electro- chem. Soc., 143 [5] 1521-25 (1990).

2. D. Simwonis, F. Tietz, and D. Stöver, "Nickel Coarsening in Annealed Ni/8YSZ Anode Substrates for Solid Oxide Fuel Cells," Solid State Ionics, 132 [3-4] 241-51 (2000).

3. J.-H. Lee, H. Moon, H.-W. Lee, J. Kim, J.-D. Kim, and K.H. Yoon, "Quantitative Analysis of Microstructure and Its Related Electrical Property of SOFC Anode, Ni-YSZ Cermet," Solid State Ionics, 148 [1-2] 15-26 (2002).

4. J.-H. Lee, J.-W. Heo, D.-S. Lee, J. Kim, G.-H. Kim, H.-W. Lee, H. S. Song, and J.-H. Moon, "The Impact of Anode Microstructure on the Power Generating Characteristics of SOFC," Solid State Ionics, 158 [3-4] 225-32 (2003).

5. R. M. C. Clemmer and S. F. Corbin, "Influence of Porous Composite Microstructure on the Processing and Property of Solid Oxide Fuel Cell anode," Solid State Ionics, 166 [34] 251-59 (2004).

6. T. Fukui, K. Murata, S. Ohara, H. Abe, M. Naito, and K. Nogi, "Morphology Control of Ni-YSZ Cermet Anode for Lower Temperature Operation of SOFCs," J. Power Sources, 125 [1] 17-8 (2004).

7. M. Marinšek, S. Pejovnik, and J. Maček, "Modelling of Electrical Properties of Ni-YSZ Composites," J. Eur. Ceram. Soc., 27 [2-3] 959-64 (2007).

8. K.-R. Lee, S. H. Choi, J. Kim, H.-W. Lee, and J.-H. Lee, "Viable Image Analyzing Method to Characterize the Microstructure and the Properties of the Ni-YSZ Cermet Anode of SOFC," J. Power Sources, 140 [2] 226-34 (2005).

9. K. Thydén, Y. L. Liu, and J. B. Bilde-Sørensen, "Microstructural Characterization of SOFC Ni-YSZ Anode Composites by Low-Voltage Scanning Electron Microscopy," Solid State Ionics, 178 [39-40] 1984-89 (2008).

10. G. F. Vander Voort, Metallography, Principles, and Practice; pp. 177-78, ASM International, Materials Park, Ohio, 2004.

11. I. J. McColm, Ceramic Hardness; pp. 235-79, Plenum Press, New York, 1990.

12. K. Higashi, K. Sonoda, H. Ono, S. Sameshima, and Y. Horata, "Synthesis and Sintering of Rare-Earth-Doped Ceria Powder by Oxalate Coprecipitation Method," J. Mater. Res., 14 [3] 957-67 (1999). 